\title{
Mineralogy, magnetic susceptibility and geochemistry of Fe-rich Oxisols developed from several parent materials
}

\author{
Danilo de Lima Camêlo ${ }^{*}$, João Carlos Ker ${ }^{2}$, Maurício Paulo Ferreira Fontes², Antonio Carlos Saraiva da Costa ${ }^{3}$, Marcelo Metri Corrêa ${ }^{4}$, \\ Matthias Leopold ${ }^{5}$
}

\begin{abstract}
'University of São Paulo/ESALQ - Dept. of Soil Science, Av. Pádua Dias, 11 - 13418-900 - Piracicaba, SP - Brazil.

${ }^{2}$ Federal University of Viçosa - Dept. of Soil Science, Av. Peter Henry Rolfs, s/n - 36570-900 - Viçosa, MG - Brazil. ${ }^{3}$ State University of Maringá - Dept. of Agronomy, Av. Colombo, 5790 - 87020-900 - Maringá, PR - Brazil. ${ }^{4}$ Federal Rural University of Pernambuco/Academic Unit of Garanhuns, Av. Bom Pastor, s/n - 55292-270 - Garanhuns, PE - Brazil.

${ }^{5}$ The University of Western Australia/School of Agriculture and Environment, 35 Stirling Highway - 6009 - Perth, WA Australia.

*Corresponding author <dlcamelosoil@gmail.com>
\end{abstract}

Edited by: Leônidas Carrijo Azevedo Melo

Received March 14, 2017

Accepted June 02, 2017
ABSTRACT: Fe-rich Oxisols on mafic rocks in Brazil generally have high magnetic susceptibility with high contents of some trace elements. These are taxonomically similar soils; however, differences in magnetic and geochemical properties may affect agricultural or environmental usability and subsequent management. This study investigated the pedogenesis of Fe-rich Oxisols from various parent materials and evaluated the lithogenetic influence on magnetic susceptibility and trace elements contents. Soil samples were collected from Bw horizons in 13 Rhodic Oxisols and a Typic Oxisol developed from several parent materials in Minas Gerais State, Brazil. Soils were analyzed by X-ray diffractometry (XRD) and magnetometry. Soil chemical analyses consisted of sulfuric and total (tri-acid) digestions and selective Fe oxides dissolutions and statistical correlations were determined. Fe-rich Oxisols presented a typical mineralogical composition of highly weathered soils with structural stability. The results confirm the difficulty to identify accurately magnetic minerals in different grain sizes using XRD. However, coarse fractions still exert dominant influence on the magnetic properties of the Fe-rich Rhodic Oxisols. In addition, coarse fractions probably contribute to the enrichment of superparamagnetic particles for the clay fraction. Although highly weathered, Fe-rich Oxisols may have their geochemical attributes still controlled by the parent material, where trace elements seem to be correlated with the magnetic minerals in the coarse fractions. Thus, the natural replacement of some trace elements from soil-solution equilibrium reactions during plant development could be more effective in soils with higher magnetic particles concentrations in the coarse fractions.

Keywords: magnetic soils, iron oxides, ferrimagnetic minerals, trace elements, mafic rocks

\section{Introduction}

Oxisols cover more than $50 \%$ of Minas Gerais State in Brazil and soils developed on basalt, tuffite and itabirite deserve attention because they are Fe-rich with high magnetic susceptibility (Ferreira et al., 1994; Fontes et al., 2000; Oliveira et al., 2000; Costa et al., 2014; Camêlo et al., 2017). These soils have high contents of hematite, maghemite and/or titanomaghemite in the clay fraction and significant amounts of magnetite and/ or titanomagnetite in silt and sand fractions, resulting in high magnetic susceptibility in the Fe-rich Rhodic Oxisols (Soil Taxonomy - Soil Survey Staff, 2014) (Fontes and Weed, 1991; Fabris et al., 1997a, b; Fontes et al., 2000). These minerals are found in soils developed from various parent materials, mainly mafic rocks.

Fe-rich Rhodic Oxisols from Brazil still require detailed information about their magnetic behavior since few studies have investigated their different grain sizes to understand the individual contribution of each fraction to soil magnetic and geochemical properties. Since coarse fractions (sand and silt) represent the reserve of soil chemical elements for the medium and long term, especially trace elements (Oliveira et al., 2000), knowing whether these fractions realistically contribute to the chemical composition of some highly weathered soils, such as the Fe-rich Rhodic Oxisols, is very important.
Magnetic minerals are known as important sources of trace elements (TE) in soils (Krauskopf, 1972; Ferreira et al., 1994; Oliveira et al., 2000; Cervi et al., 2014; Costa et al., 2014). Despite a consensus on the relationship between magnetic minerals and TE in soils, Oliveira et al. (2000) highlighted that this relationship is not observed for Fe-rich soils developed on itabirite. However, considerable contents of $\mathrm{Cd}, \mathrm{Cr}, \mathrm{Ni}, \mathrm{Zn}$ and $\mathrm{Cu}$ may occur in the magnetic fractions of these soils.

Understanding the relationship between the parent material and the soil magnetic and geochemical properties could provide significant information on weathering processes, which may influence any agricultural or environmental use and subsequent management. Therefore, in this work we investigated the pedogenesis of Fe-rich Oxisols developed from several parent materials in Minas Gerais State, Brazil and evaluated the influence of parent material on magnetic susceptibility and TE contents.

\section{Materials and Methods}

\section{Soil sampling}

To highlight differences in TE contents and magnetic susceptibility values in Oxisols up to the $4^{\text {th }}$ category level in Brazilian System of Soil Classification (Embra$\mathrm{pa}, 2013), 13 \mathrm{Bw}$ horizons of ferric Rhodic Oxisols $\left(\mathrm{Fe}_{2} \mathrm{O}_{3}\right.$ contents between $180 \mathrm{~g} \mathrm{~kg}^{-1}$ and $360 \mathrm{~g} \mathrm{~kg}^{-1}-\mathrm{LV}_{1}, \mathrm{LV}_{2^{\prime}}$ $\mathrm{LV}_{3^{\prime}} \mathrm{LV}_{5^{\prime}} \mathrm{LV}_{6^{\prime}} \mathrm{LV}_{10^{\prime}} \mathrm{LV}_{12}$ and $\mathrm{LV}_{13}$ ) and perferric Rhodic 
Oxisols $\left(\mathrm{Fe}_{2} \mathrm{O}_{3}\right.$ contents greater than $360 \mathrm{~g} \mathrm{~kg}^{-1}-\mathrm{LV}_{4^{\prime}}$ $\mathrm{LV}_{7}, \mathrm{LV}_{8}, \mathrm{LV}_{9}$ and $\mathrm{LV}_{11}$ ) and only one Bw horizon of a mesoferric Typic Oxisol $\left(\mathrm{Fe}_{2} \mathrm{O}_{3}\right.$ contents between $80 \mathrm{~g} \mathrm{~kg}^{-1}$ and $180 \mathrm{~g} \mathrm{~kg}^{-1}-\mathrm{LVA}_{1}$ ), developed from several parent materials were investigated (Figure 1). The taxonomic classification of soils from the $\mathrm{Fe}_{2} \mathrm{O}_{3}$ content is based on values determined by sulphuric acid digestion of the soils (Embrapa, 2013). Samples were collected from Bw horizons at 0.8-1.0 $\mathrm{m}$ depth in Minas Gerais State, Brazil, developed on basalt $\left(\mathrm{LV}_{1}, \mathrm{LV}_{2}, \mathrm{LV}_{3}\right.$ and $\left.L V_{4}\right)$, tuffite $\left(\mathrm{LV}_{5}, \mathrm{LV}_{6}, \mathrm{LV}_{7}, \mathrm{LV}_{8}, \mathrm{LV}_{9}, \mathrm{LV}_{10}\right.$ and $\left.\mathrm{LVA}_{1}\right)$, itabirite $\left(\mathrm{LV}_{11}\right)$, amphibolite $\left(\mathrm{LV}_{12}\right)$ and gabbro $\left(\mathrm{LV}_{13}\right)$.

After collection, the soil samples were air-dried, gently crumbled and sieved through a 2-mm mesh to obtain the air-dried fine earth (ADFE).

\section{Mineralogical and magnetic analysis of soils}

To separate particle size fractions, ADFE samples were subjected to slow shaking (16 h) in a vertical shaker with $\mathrm{NaOH} 0.1 \mathrm{~mol} \mathrm{~L}^{-1}$ as chemical dispersant. The sand fraction was retained on a $53 \mu \mathrm{m}$ sieve and then the clay and silt fractions were separated by sedimentation based on the Stoke's Law (Jackson, 1979).

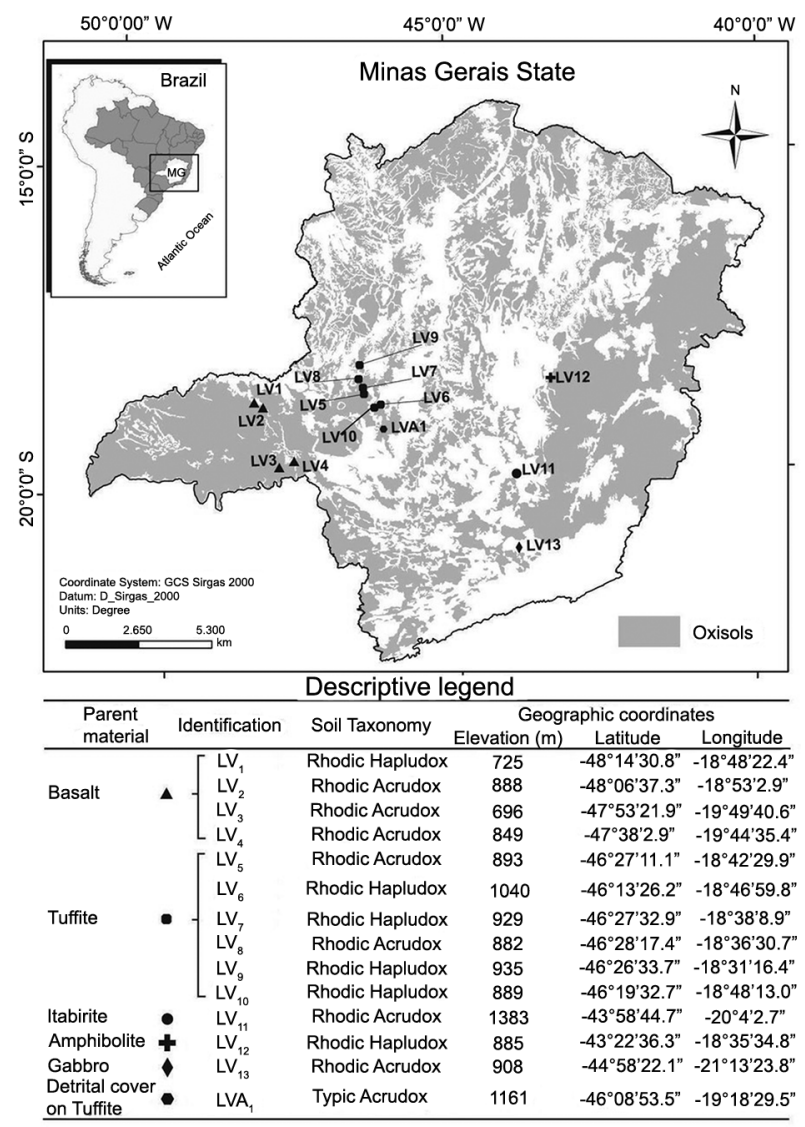

Figure 1 - Distribution map of Oxisols in Minas Gerais State with coordinates, parent material and soil classification according to the U.S. Soil Taxonomy (Soil Survey Staff, 2014) of the soils studied.
Minerals of sand, silt and clay fractions were identified by X-ray diffractometry (XRD) using an X'PERT PRO PANALYTICAL equipment with $\mathrm{CoK} \alpha$ radiation operated at $40 \mathrm{kV}$ and $30 \mathrm{~mA}$, scanning from 4 to $50{ }^{\circ} 2 \theta$, in $0.01^{\circ} 2 \theta / \mathrm{s}$ steps. The untreated clay fraction was transferred to glass slides, slightly moistened with deionized water and mounted with the aid of another slide until a uniform film was obtained (oriented slides). After water evaporation, the glass slides were analyzed by XRD. Sand, silt and clay fraction treated with $\mathrm{NaOH} 5 \mathrm{~mol}$ $\mathrm{L}^{-1}$ for concentration of Fe oxides (Norrish and Taylor, 1961), were analyzed by the powder method.

The volumetric magnetic susceptibility $(\kappa$, dimensionless) was determined for aliquots of $10 \mathrm{~cm}^{3}$ of ADFE, sand and clay fractions previously diluted in an inert medium (sacarose) to reach the necessary volume. Measurements were carried out in low $\left(\kappa_{\mathrm{LF}}\right)(0.47 \mathrm{kHz})$ and high frequency $\left(\kappa_{\mathrm{HF}}\right)(4.70 \mathrm{kHz})$ settings using the MS2 Bartington system coupled to an MS2B sensor. The magnetic susceptibility per mass unit $\left(\chi_{\mathrm{LF}^{\prime}} 10^{-8} \mathrm{~m}^{3}\right.$ $\mathrm{kg}^{-1}$ ) was calculated from the volumetric susceptibility by the equation: $\chi_{\mathrm{LF}}=\left(10 \times \kappa_{\mathrm{LF}}\right) / m$ (where $m$ is the mass of the used sample) and the frequency dependent magnetic susceptibility $\left(\chi_{\mathrm{FD}}, \%\right)$ by the equation: $\chi_{\mathrm{FD}}=$ $100 \times\left[\left(\chi_{\mathrm{LF}}-\chi_{\mathrm{HF}}\right) / \chi_{\mathrm{LF}}\right]$ (Dearing, 1999).

\section{Soil chemical analysis}

Iron, $\mathrm{Al}$ and $\mathrm{Ti}$ were extracted from ADFE using sulfuric acid digestion (diluted with water, 1:1 ratio of $\left.\mathrm{H}_{2} \mathrm{SO}_{4}\right)\left(\mathrm{Fe}_{\mathrm{s}^{\prime}} \mathrm{Al}_{\mathrm{s}}\right.$ and $\left.\mathrm{Ti}_{\mathrm{s}}\right)$ and were determined by atomic absorption spectrometry according to Embrapa (2011). For that purpose, $1 \mathrm{~g}$ of ADFE samples were ground, sieved through a $0.5-\mathrm{mm}$ mesh and added to $75 \mathrm{~mL}$ tubes along with $20 \mathrm{~mL}$ of diluted $\mathrm{H}_{2} \mathrm{SO}_{4}$. Then, the samples were taken to a digesting plate block and remained there under heating at $180{ }^{\circ} \mathrm{C}$ for 30 min after boiling. After cooling down, the extracts were diluted with $50 \mathrm{~mL}$ of distilled water and filtered with $2 \mu \mathrm{m}$ filter paper in $250 \mathrm{~mL}$ volumetric flasks (Embrapa, 2011).

Clay samples were subjected to five successive extractions with Na-citrate-bicarbonate-dithionite for complete removal of pedogenic Fe oxides (Mehra and Jackson, 1960) and only one extraction with $1.8 \mathrm{~mol}$ $\mathrm{L}^{-1} \mathrm{H}_{2} \mathrm{SO}_{4}$ at $80{ }^{\circ} \mathrm{C}$ for $2 \mathrm{~h}$ for selective Fe dissolution of maghemite (Schwertmann and Fechter, 1984, modified by Costa et al., 1999). The extracted $\mathrm{Fe}\left(\mathrm{Fe}_{d}\right.$ and $\mathrm{Fe}_{\mathrm{H}_{2 \mathrm{SO}}}$ / was measured by atomic absorption spectrometry and numerical values were presented by Camêlo et al. (2017).

Total $\mathrm{Co}, \mathrm{Cr}, \mathrm{Cu}, \mathrm{Mn}, \mathrm{Ni}, \mathrm{Pb}$, and $\mathrm{Zn}$ concentrations were determined for $0.5 \mathrm{~g}$ of ADFE, sand, silt and clay and the magnetic sand fraction (separated by a hand magnet) in a Teflon beaker with $1 \mathrm{~cm}$ walls, using perchloric $\left(\mathrm{HClO}_{4}\right)$, nitric $\left(\mathrm{HNO}_{3}\right)$, hydrofluoric $(\mathrm{HF})$ and hydrochloric $(\mathrm{HCl})$ acids (Soltanpour et al., 1996). The extracts were analyzed by inductively coupled plasma optical emission spectrometry (ICP-OES) according to Soltanpour et al. (1996). 


\section{Data analysis}

The Pearson's correlation coefficients and regressions for the variables were determined using Statistica software (version 7.0).

\section{Results and Discussion}

\section{Mineralogical composition}

XRD patterns of clay, silt and sand fractions showed a simple mineralogical assembly in the soils. Quartz and magnetite/maghemite are the main constituents in silt and sand fractions while gibbsite, hematite, anatase and magnetite/maghemite in the clay fraction, corroborating other Brazilian authors (Curi and Franzmeier, 1987; Fontes et al., 2000; Costa et al., 2014; Cervi et al., 2014; Carvalho Filho et al., 2015) (Figures 2A, B and $\mathrm{C} ; 3 \mathrm{~A}, \mathrm{~B}$ and $\mathrm{C}$; and $4 \mathrm{~A}, \mathrm{~B}$ and $\mathrm{C})$. XRD patterns did not allow to differ clearly magnetite and maghemite in the soil fractions (Fontes et al., 2000). Nevertheless, XRD patterns with different intensity of $\mathrm{d}_{311}$ reflection of these minerals between the soil fractions were observed.

In general, in the clay fraction (Figure 2A, B and C), almost all soils showed low intensity of $\mathrm{d}_{001}$ reflection of kaolinite, highlighting the small percentage of this mineral in the soil mineralogical composition due to the mafic nature of materials. Exception was observed for profiles $L V_{1}, L_{12}$ and $L_{13}$, whose parent material contributed with enough silica contents in the system to maintain higher kaolinite contents.

For $\mathrm{LV}_{1}$, greater $\mathrm{d}_{001}$ reflection intensity was observed for kaolinite, possibly due to reworking of the parent material with detrital materials from surface sediments in Central Brazil. On the other hand, the high degree of metamorphism (massive structure) and phaneritic particle size of minerals in the parent materials from $L_{12}$ and $L V_{13}$ soils, respectively, hinder weathering and thus slow down silica release, increasing kaolinite chemical stability and occurrence even in these highly weathered soils.

Gibbsite was identified in all soil samples by its well defined $\mathrm{d}_{002}$ and $\mathrm{d}_{110}$ reflections, which suggests low silicon content of parent materials and intense desilication suffered by the soils during pedogenesis.

In the clay fraction, anatase $\left(\mathrm{TiO}_{2}\right)$ was identified by $d_{101}$ reflection in all soils studied but mainly in soils developed on tuffite (Figure 2B), indicating that this mineral is the main source of $\mathrm{Ti}$ in these soils.

Although XRD patterns showed weak evidence in all soils for the occurrence of goethite in the clay fraction, goethite was not observed only in $\mathrm{LV}_{9}$ after the Fe oxides concentration treatment (Camêlo et al., 2017).

Hematite was identified by $\mathrm{d}_{104}$ and $\mathrm{d}_{110}$ reflections and magnetite/maghemite by $\mathrm{d}_{220}$ reflection. Hematite $\mathrm{d}_{110}$ reflection had higher intensity then that of $\mathrm{d}_{104}$ due to the overlap with the $d_{311}$ magnetite/maghemite reflections for coarse and clay fractions (Costa et al., 1999; Silva et al., 2010). The lower intensity of the corresponding $\mathrm{d}_{220}$ reflection of magnetite/maghemite for the clay fraction (Figure 2A, B and C), contrary to what was observed for the silt and sand fractions (Figures 3A, B and $\mathrm{C}$; and 4A, B and C), suggests magnetic susceptibility of soils mainly related to coarse fractions.

In silt and sand fractions, common minerals of the clay fraction, such as kaolinite, anatase, goethite, hematite and gibbsite, were also identified in all soils (Figures

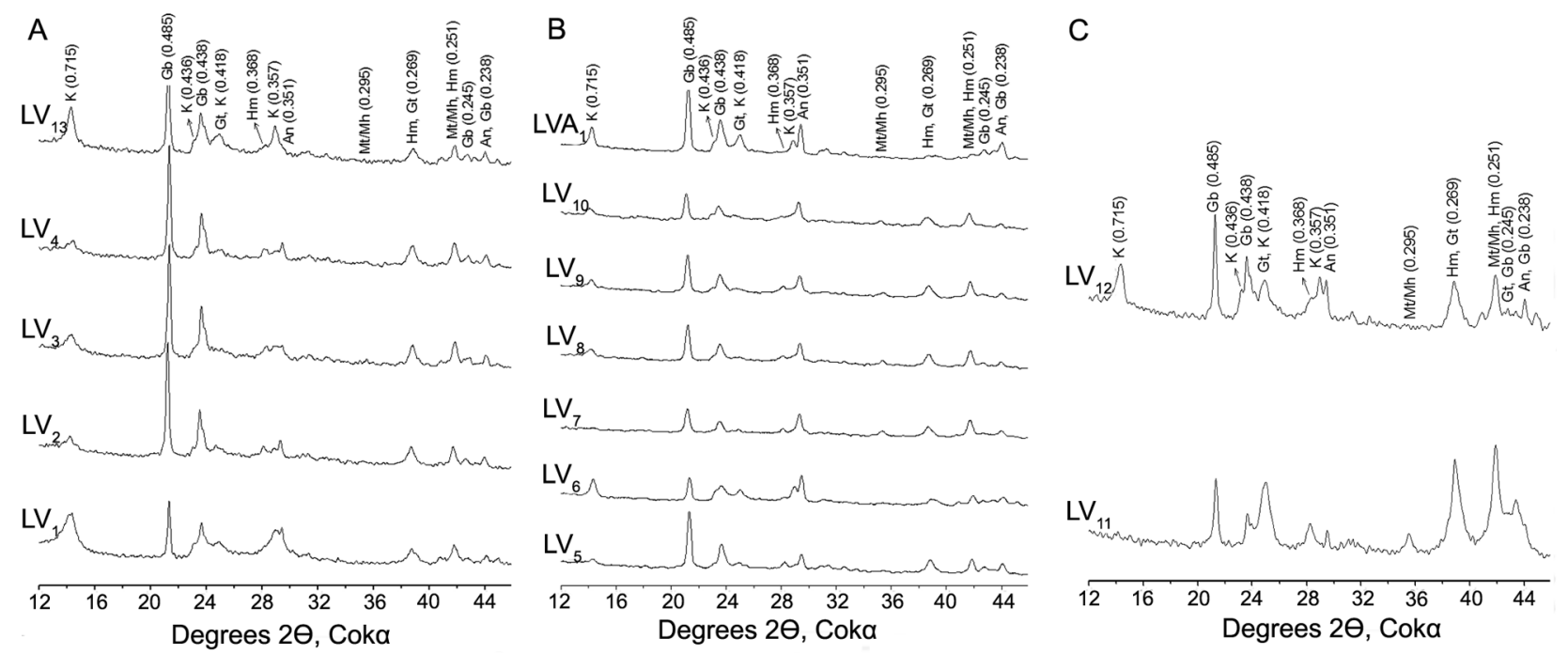

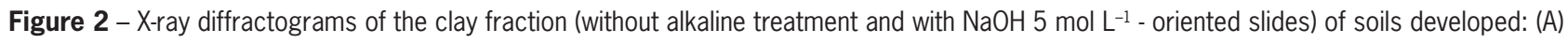
on basalt $\left(\mathrm{LV}_{1}, \mathrm{LV}_{2}, \mathrm{LV}_{3}, \mathrm{LV}_{4}\right)$ and gabbro $\left(\mathrm{LV}_{13}\right)$, (B) on tuffite $\left(\mathrm{LV}_{5}, \mathrm{LV}\right.$, $\mathrm{LV}$, $\left.\mathrm{LV}_{8}, \mathrm{LV}_{9}, \mathrm{LV}_{10}, \mathrm{LVA}_{1}\right),(\mathrm{C})$ on itabirite $\left(\mathrm{LV}_{11}\right)$ and amphibolite $\left(\mathrm{LV}_{12}\right) ; \mathrm{K}=$ kaolinite; $\mathrm{Gb}$ = gibbsite; $\mathrm{Gt}$ = goethite; $\mathrm{Hm}$ = hematite; $\mathrm{An}$ = anatase; $\mathrm{Mt} / \mathrm{Mh}$ = magnetite and/or maghemite; Numbers between parentheses correspond to distance between adjacent planes in nanometers $(\mathrm{nm})$ expressed in three decimal places. 
3A, B and C; and 4A, B and C). The presence of these minerals in the coarse fractions is an indicative of the high stability of microgranular aggregates, hindering particles dispersion by conventional chemical and physical dispersion treatments in these Oxisols. Microaggregate stability, along with similar XRD patterns of the magnetite/maghemite, does not allow a clear differentiation of these minerals in different soil fractions (Fontes et al., 2000). Thus, maghemite typically observed in the clay fraction may also be present in the silt and sand fractions. In these fractions, the presence of $d_{311}$ and $d_{220}$ reflections are generally associated to magnetite presence usually found in coarse fractions (Fontes and Weed, 1991; Fontes et al., 2000). Only LVA did not present characteristic reflections of magnetic minerals.

Quartz was the dominant mineral in the coarse fractions (Figure $3 \mathrm{~A}, \mathrm{~B}$ and $\mathrm{C}$; and $4 \mathrm{~A}, \mathrm{~B}$ and $\mathrm{C}$ ) and characteristic reflections of this mineral were not observed for the clay fraction (Figures 2A, B and C), as found in some soils of southeastern Brazil (Inda et al., 2013; Costa et al., 2014).

Ilmenite $\left(\mathrm{FeTiO}_{3}\right)$ was identified by $\mathrm{d}_{104}$ reflection in the sand fraction only in soils developed on basalt and gabbro (Figure 4A). Similar behavior was observed in

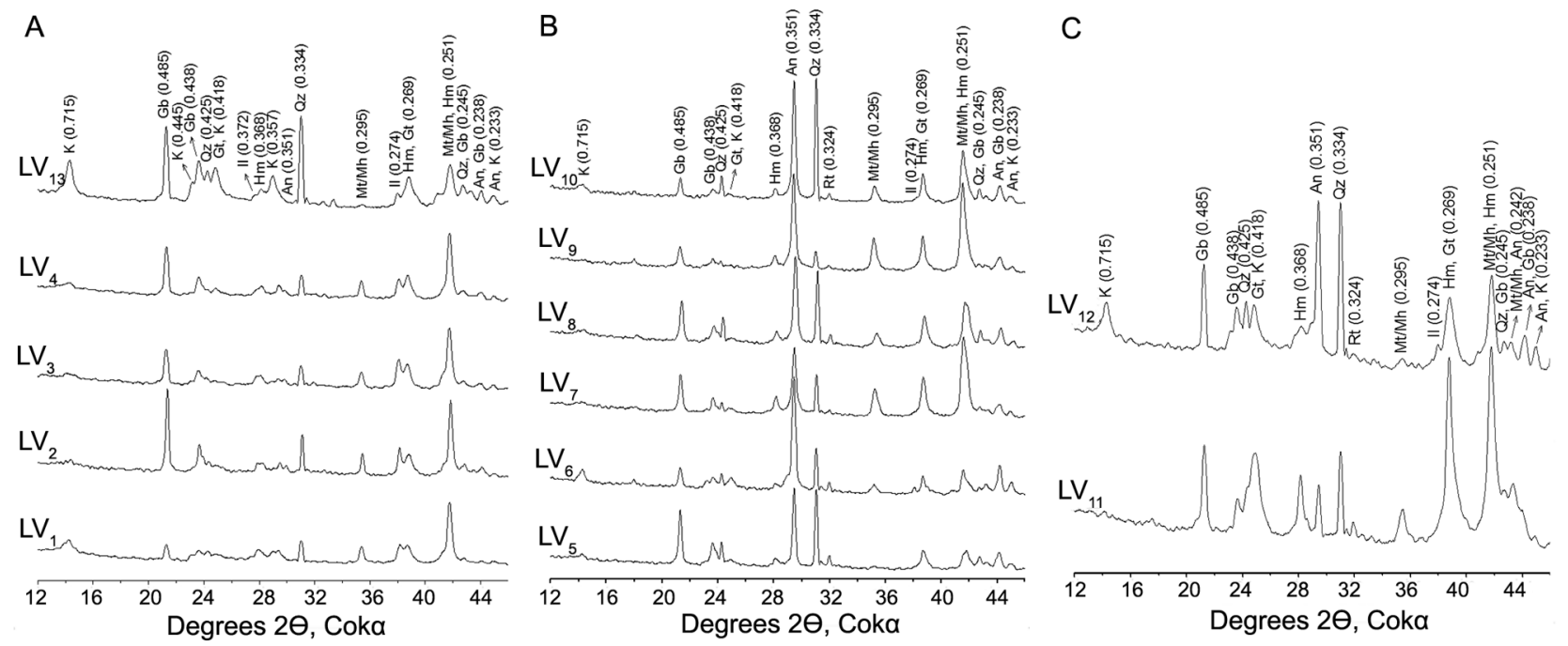

Figure 3 - X-ray diffractograms of the silt fraction (powder method) of soils developed: (A) on basalt $\left(\mathrm{LV}_{1}, \mathrm{LV}_{2}, \mathrm{LV}_{3}, \mathrm{LV}_{4}\right)$ and gabbro $\left(\mathrm{LV}_{13}\right)$, $(B)$ on tuffite $\left(\mathrm{LV}_{5}, \mathrm{LV}_{6}, \mathrm{LV}_{7}, \mathrm{LV}_{8}, \mathrm{LV}_{9}, \mathrm{LV}_{10}, \mathrm{LVA}_{1}\right)$, (C) on itabirite $\left(\mathrm{LV}_{11}\right)$ and amphibolite $\left(\mathrm{LV}_{12}\right) ; \mathrm{K}=$ kaolinite; $\mathrm{Gb}=$ gibbsite; Qz = quartz; $\mathrm{Gt}=$ goethite; $\|$ = ilmenite; $\mathrm{Hm}$ = hematite; $\mathrm{An}=$ anatase; $\mathrm{Rt}$ = rutile; $\mathrm{Mt} / \mathrm{Mh}$ = magnetite and/or maghemite; Numbers between parentheses correspond to distance between adjacent planes in nanometers $(\mathrm{nm})$ expressed in three decimal places.
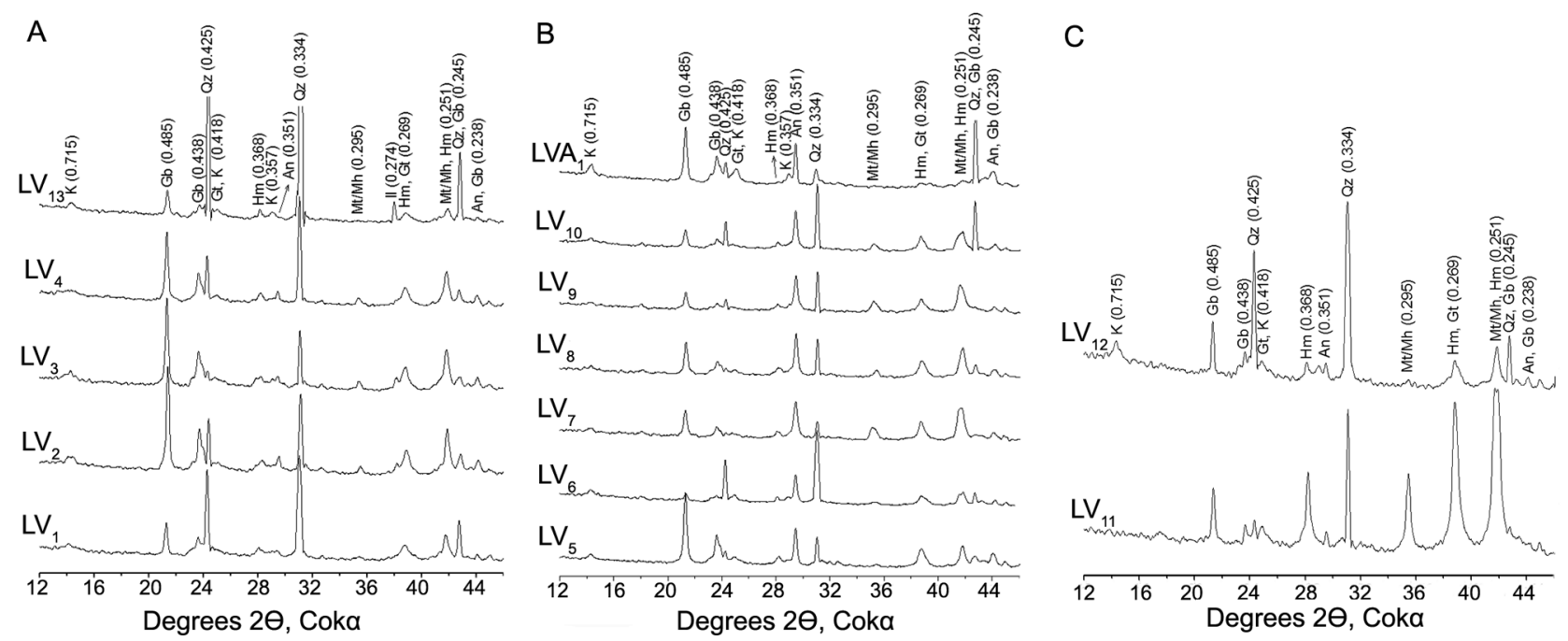

Figure 4 - X-ray diffractograms of the sand fraction (powder method) of soils developed: (A) on basalt $\left(\mathrm{LV}_{1}, \mathrm{LV}_{2}, \mathrm{LV}_{3}, \mathrm{LV}_{4}\right)$ and gabbro $\left(\mathrm{LV}_{13}\right),(\mathrm{B})$ on tuffite $\left(\mathrm{LV}_{5}, \mathrm{LV}_{6}, \mathrm{LV}_{7}, \mathrm{LV}_{8}, \mathrm{LV}_{9}, \mathrm{LV}_{10}, \mathrm{LVA}_{1}\right)$, (C) on itabirite $\left(\mathrm{LV}_{11}\right)$ and amphibolite $\left(\mathrm{LV}_{12}\right) ; \mathrm{K}=$ kaolinite; $\mathrm{Gb}=$ gibbsite; $\mathrm{Qz}=$ quartz; $\mathrm{Gt}=$ goethite; $\|$ = ilmenite; $\mathrm{Hm}$ = hematite; $\mathrm{An}=$ anatase; $\mathrm{Mt} / \mathrm{Mh}$ = magnetite and/or maghemite; Numbers between parentheses correspond to distance between adjacent planes in nanometers $(\mathrm{nm})$ expressed in three decimal places. 
the silt fraction with even more pronounced reflections in soils formed on basalt $\left(\mathrm{LV}_{1}, \mathrm{LV}_{2}, \mathrm{LV}_{3}\right.$ and $\left.\mathrm{LV}_{4}\right)$, gabbro $\left(\mathrm{LV}_{13}\right)$ and in soils $\mathrm{LV}_{6}$ and $\mathrm{LV}_{12}$ originating from tuffite and amphibolite, respectively (Figure $3 \mathrm{~A}, \mathrm{~B}$ and $\mathrm{C}$ ). In this fraction, the primary mineral rutile was also identified by $d_{110}$ reflection well expressed in soils $L_{5}, L V_{6}$, $\mathrm{LV}_{8}, \mathrm{LV}_{10}$ and $\mathrm{LV}_{11}$ and little expressed in $\mathrm{LV}_{7}$ and $\mathrm{LV}_{9}$.

\section{Mass specific magnetic susceptibility}

The mass specific magnetic susceptibility $\left(\chi_{\mathrm{LF}}\right)$ values, or simply magnetic susceptibility, of the Bw horizons varied in all fractions analyzed (Table 1$)$. In addition to the lithological influence $(\mathrm{Lu}, 2000 ; \mathrm{Lu}, 2003$; Hanesch et al., 2007; Silva et al., 2010; Camargo et al., 2014; Cervi et al., 2014), pedogenesis (Hanesch et al., 2007; Lu et al., 2008) and wetter pedoenvironmental conditions (Curi and Franzmeier, 1984) might also have contributed to the difference in proportions of ferrimagnetic minerals.

The highest $\chi_{\mathrm{LF}}$ values of ADFE were observed for basalt soils (except for $L_{1}$ ) and $L V_{11}$, which is derived from itabirite. In $L_{1}$, reworking of parent material with detrital superficial sediments in South America favored the formation of the diamagnetic kaolinite diluting the concentration of ferrimagnetic (magnetite and maghemite), determining lower $\chi_{\mathrm{LF}}$ values observed in basalt soils. Costa et al. (1999), Silva et al. (2010) and Cervi et al. (2014) studied soils of Paraná State, Brazil, and found $\chi_{\mathrm{LF}}$ values in ADFE and different soil fractions ranging from less than 1,000 to more than 10,000 $\times 10^{-8} \mathrm{~m}^{3} \mathrm{~kg}^{-1}$ in different soil classes formed from the weathering of igneous rocks (basalt and diabase) of the Serra Geral Formation.

As reported by Curi and Franzmeier (1987), the highest $\chi_{\mathrm{LF}}$ values observed in the sand fraction of $\mathrm{LV}_{11}$ derived from itabirite may be related to the greater magnetite content in this fraction compared to the other soils studied, supported by intensities of $\mathrm{d}_{311}$ and $\mathrm{d}_{220}$ reflections of this mineral (Figure 4C).

The significant correlation $\left(R^{2}=0.89, p<0.01, n\right.$ $=14$ ) observed between $\chi_{\mathrm{LF}}$ values of sand and clay fractions confirm a very close association between magnetic minerals found in coarse and fine fractions, suggesting contribution of coarse fractions to ferrimagnetic mineral content in the clay fraction during the soil weathering process (Figure 5). This is consistent with the nature of parent materials, since all had high magnetization. Magnetite oxidation to maghemite in the clay fraction of soils derived from itabirite and basalt was previously reported by Curi and Franzmeier (1987) and Fontes and Weed (1991).

The lower $\chi_{\mathrm{LF}}$ values found in soils $\mathrm{LV}_{6}$ and LVA (Table 1) show the heterogeneous nature of tuffite and the influence of lateritic detrital sediment coverage, more pronounced in $\mathrm{LVA}_{1}$. In addition, the preferential dissolution of maghemite over hematite in soils under

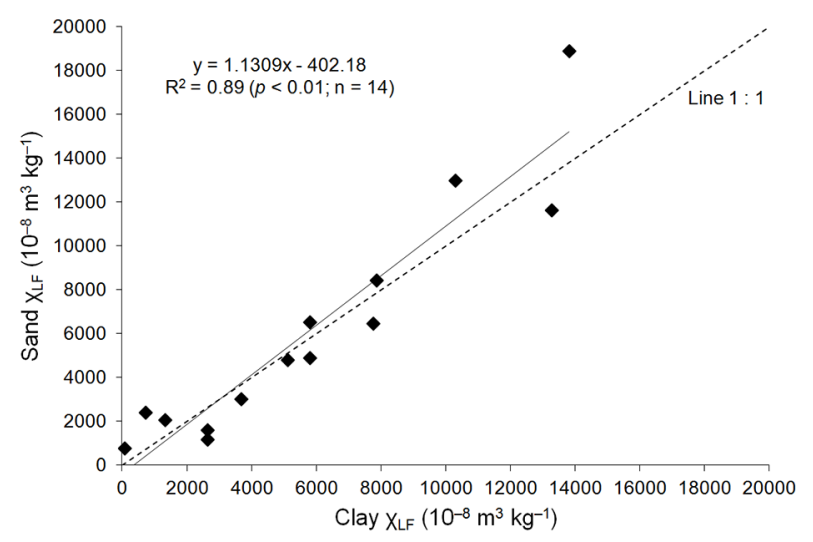

Figure 5 - Relationship between mass specific magnetic susceptibilities $\left(\chi_{\mathrm{LF}}\right)$ determined in the sand and clay fractions.

Table 1 - Mass specific $\left(\chi_{\mathrm{LF}}\right)$ and dependent frequency $\left(\chi_{\mathrm{FD}}\right)$ magnetic susceptibility values for different particle sizes of $0 x i s o l s$.

\begin{tabular}{|c|c|c|c|c|c|c|c|}
\hline \multirow{2}{*}{ Soil } & \multirow{2}{*}{ Parent material } & \multicolumn{3}{|c|}{$\chi_{\text {LF }}$} & \multicolumn{3}{|c|}{$\chi_{\mathrm{FD}}$} \\
\hline & & ADFE & Sand & Clay & ADFE & Sand & Clay \\
\hline & & \multicolumn{3}{|c|}{ 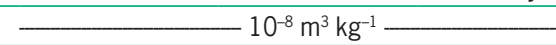 } & -2 & $-\%$ & \\
\hline $\mathrm{LV}_{1}$ & Basalt & 4,330 & 1,600 & 2,640 & 6.9 & 2.8 & 13.5 \\
\hline $\mathrm{LV}_{2}$ & Basalt & 7,030 & 4,910 & 5,790 & 10.3 & 8.5 & 14.0 \\
\hline $\mathrm{LV}_{3}$ & Basalt & 7,310 & 6,540 & 5,810 & 10.2 & 7.1 & 14.8 \\
\hline $\mathrm{LV}_{4}$ & Basalt & 6,800 & 4,810 & 5,110 & 9.5 & 5.8 & 14.2 \\
\hline $\mathrm{LV}_{5}^{4}$ & Tuffite & 3,730 & 3,020 & 3,680 & 16.8 & 6.3 & 15.6 \\
\hline $\mathrm{LV}_{6}^{3}$ & Tuffite & 1,120 & 2,400 & 717 & 10.2 & 0.3 & 15.0 \\
\hline $\mathrm{LV}_{7}$ & Tuffite & 5,650 & 13,000 & 10,300 & 5.6 & 2.5 & 9.3 \\
\hline $\mathrm{LV}_{8}$ & Tuffite & 4,450 & 8,440 & 7,870 & 10.1 & 2.8 & 10.6 \\
\hline $\mathrm{LV}_{9}$ & Tuffite & 5,320 & 11,630 & 13,280 & 6.0 & 2.7 & 9.3 \\
\hline $\mathrm{LV}_{10}$ & Tuffite & 3,450 & 6,480 & 7,750 & 10.4 & 1.8 & 12.3 \\
\hline $\mathrm{LV}_{11}$ & Itabirite & 7,170 & 18,890 & 13,820 & 5.8 & 2.2 & 9.8 \\
\hline $\mathrm{LV}_{12}$ & Amphibolite & 1,470 & 2,070 & 1,320 & 12.2 & 1.9 & 15.7 \\
\hline $\mathrm{LV}_{13}$ & Gabbro & 2,460 & 1,180 & 2,640 & 17.3 & 1.6 & 16.0 \\
\hline $\mathrm{LVA}_{1}$ & Detrital cover on Tuffite & 183 & 775 & 85 & 7.7 & 3.7 & 10.2 \\
\hline
\end{tabular}

$\overline{\mathrm{ADFE}}=$ air-dried fine earth. 
wetter pedoclimatic conditions or restricted drainage promote a sharp reduction in $\chi_{\mathrm{LF}}$ values, both in clay and other soil fractions (Curi and Franzmeier, 1984). This is supported by yellower hues (> $2.5 \mathrm{YR}$ ) of these soils, 5 YR in $\mathrm{LVA}_{1}$, which presented the lowest $\chi_{\mathrm{LF}}$ values in all fractions studied.

Although ferrimagnetic minerals (magnetite and/ or maghemite) were not identified by XRD in LVA (Figures $2 \mathrm{~B}$ and $4 \mathrm{~B}$ ), $\chi_{\mathrm{LF}}$ measurements (Table 1 ) indicate their presence in that soil type. This shows that $\chi_{\mathrm{LF}}$ measurements are more sensitive to the detection of ferrimagnetic minerals compared to XRD measurements when the default setup of the equipment is used (Silva et al., 2010).

The $\mathrm{Fe}_{\mathrm{s}}$ content showed significant correlation $\left(R^{2}\right.$ $>0.58, p<0.01, n=14$ ) with $\chi_{\mathrm{LF}}$ values (Figures 6A, $\mathrm{B}$ and $\mathrm{C})$, highlighting participation of parent material in the expression of soil magnetic properties $(\mathrm{Lu}, 2000$; Lu, 2003; Hanesch et al., 2007; Silva et al., 2010; Camargo et al., 2014; Cervi et al., 2014; Carvalho Filho et al., 2015). However, soils with low $\mathrm{Fe}_{\mathrm{s}}$ content present low magnetic susceptibility, regardless of the color (Silva et al., 2010).

$\chi_{\mathrm{FD}}$ values also varied greatly between independent samples of the different fractions analyzed (Table $1)$, with averages of 9.9, 3.6 and $12.9 \%$ for the ADFE, sand and clay, respectively. In $\mathrm{ADFE}, \chi_{\mathrm{FD}}$ values were above $14 \%$ for soils $L_{5}$ and $L_{13}$, which may be attributed to analytical errors, according to Dearing (1999); however, this variation was probably due to the large content of superparamagnetic particles, common in soils developed on basic rocks (Costa et al., 1999; Silva et al., 2010). Therefore, due to the high amounts of these particles in the clay fraction, $\chi_{\mathrm{FD}}$ values were above $14 \%$ in several soils. $\chi_{\mathrm{FD}}$ values near $2 \%$ was observed in the sand fraction dominated by multidomain magnetic particles. However, almost all basalt soils $\left(\mathrm{LV}_{2}, \mathrm{LV}_{3}\right.$ and $\left.\mathrm{LV}_{4}\right)$ and one tuffite soil $\left(\mathrm{LV}_{5}\right)$ showed much higher values probably because of the difficulty to remove mineral microaggregates from the clay fraction, as evidenced by mineralogy.

The high $\chi_{\mathrm{FD}}$ values for ADFE indicates a mixture of multidomain and superparamagnetic particles caused by the presence of magnetite probably inherited from the parent rock (Maher, 1986). In this case, magnetite weathering of multidomain magnetic particles and secondary formation of magnetite/maghemite superparamagnetic particles could contribute to the increase of $\chi_{\mathrm{FD}}$ values in soils (Fontes and Weed, 1991; Costa et al., 1999; Dearing, 1999).

Soils $\mathrm{LV}_{7}, \mathrm{LV}_{9}$ and $\mathrm{LV}_{11}$ were formed from different parent materials; nevertheless, they had very similar magnetic behavior, showing higher $\chi_{\mathrm{LF}}$ and lower $\chi_{\mathrm{FD}}$ values in clay and sand fractions. However, $\chi_{L F}$ values for $\mathrm{LV}_{11}$ for the sand fraction are far higher than the others, indicating a greater influence of multidomain magnetic particles on magnetic properties of this soil (Curi and Franzmeier, 1987).

The Pearson's correlation coefficients were calculated disregarding the LVA 1 soil due to strong influence of pedogenetic processes, mainly goethitization, on $\chi_{\mathrm{LF}}$ and $\chi_{\mathrm{FD}}$ values.

Positive and significant relationships between $\chi_{\mathrm{FD}}$ values of the clay fraction and clay content $\mid r=0.85, p$ $<0.01, n=13)$ and $\mathrm{Al}_{\mathrm{s}}$ content $(r=0.81, p<0.01, n=$ 13) were verified. Lu (2000) and Lu et al. (2008) reported significant positive correlation between $\chi_{\mathrm{FD}}$ values and some weathering indexes, such as the clay content, $\mathrm{Fe}_{\mathrm{d}}$ and $\mathrm{Fe}_{\mathrm{d}} / \mathrm{Fe}_{\mathrm{t}}$ ratio, indicating the enrichment of $\mathrm{Fe}$ oxides with superparamagnetic behavior in the soil weathering process, highlighting the usefulness of $\chi_{\mathrm{FD}}$ as a pedogenetic indicator. Nevertheless, the negative relationship observed for the clay fraction between $\chi_{\mathrm{FD}}$ and $\mathrm{Fe}_{\mathrm{d}}(r=$ $-0.63, p<0.05, n=13)$ and $\mathrm{Fe}_{\mathrm{H} 2 \mathrm{SO} 4}(r=-0.80, p<0.01$, $n=13$ ) values suggests that coarse fractions still plays a dominant role in the magnetic expression of the Rhodic Oxisols. This argument is supported by the negative relationship $(r=-0.90, p<0.01, n=13)$ between $\chi_{\mathrm{LF}}$ and $\chi_{\mathrm{FD}}$ values for the clay fraction.

According to $\mathrm{Lu}$ et al. (2008), $\chi_{\mathrm{LF}}$ is not a good pedogenetic indicator for soils developed on basic rocks with high magnetic susceptibility, such as basalt, because as weathering reactions advance, sharp reductions of their values are observed. According to the explanatory model generated by the authors, after magnetite is released from the parent material, it is oxidized and con-
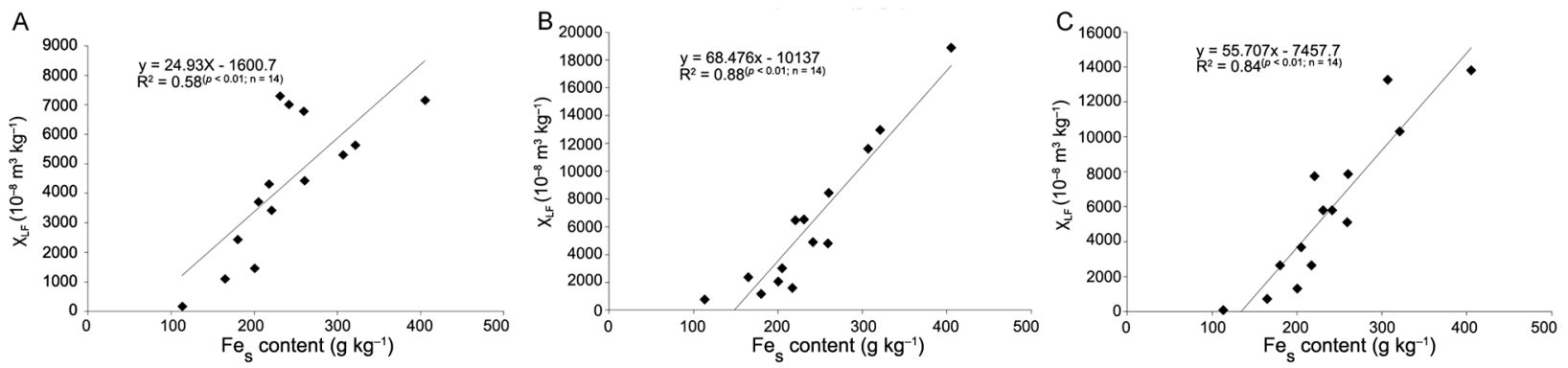

Figure 6 - Mass specific magnetic susceptibility $\left(\chi_{L F}\right)$ determined in ADFE (air-dried fine earth) (A), sand (B) and clay (C) fractions based on Fe content obtained by sulphuric digestion in ADFE. 
verted to maghemite, which may be transformed into hematite with pedogenetic development (Torrent et al., 2006). Conversely, positive and significant correlations were observed between $\chi_{\mathrm{LF}}$ values of the sand $(r=0.84$, $p<0.01, n=13)$ and clay $(r=0.76, p<0.01, n=13)$ fractions and $\mathrm{Fe}_{\mathrm{d}}$ values. This was also reported by $\mathrm{Lu}$ (2000) for the ADFE $\chi_{\mathrm{LF}}$ values. Therefore, the negative correlation $(r=-0.92, p<0.01, n=13)$ observed between $\chi_{\mathrm{LF}}$ values of the clay fraction and clay contents reinforces the relevance of coarse fractions in expression of the soil magnetic properties.

\section{Geochemistry}

Cobalt, $\mathrm{Cr}, \mathrm{Cu}, \mathrm{Mn}, \mathrm{Ni}, \mathrm{Pb}$ and $\mathrm{Zn}$ contents are within the limits of normally found in Brazilian soils (Oliveira et al., 2000; Marques et al., 2004; Cervi et al., 2014). Despite variations in different soil fractions, when observed the magnetic sand fraction for example, with the highest $\left(8,252 \mathrm{mg} \mathrm{kg}^{-1}\right)$ and the lowest $(1,079$ $\mathrm{mg} \mathrm{kg}{ }^{-1}$ ) values for the $\mathrm{LV}_{9}$ (tuffite) and $\mathrm{LV}_{11}$ (itabirite), respectively, the general distribution of the total heavy metal contents in the soil was identified (Figure 7). It suggested a clear relationship with the parent material, as reported in previous studies (Curi and Franzmeier, 1987; Ferreira et al., 1994; Oliveira et al., 2000; Marques et al., 2004; Cervi et al., 2014; Costa et al., 2014).

The highest values of the sum of TE concentrations for ADFE were observed for $\mathrm{LV}_{7}\left(4,186 \mathrm{mg} \mathrm{kg}^{-1}\right)$ and $\mathrm{LV}_{9}\left(6,487 \mathrm{mg} \mathrm{kg}^{-1}\right)$ developed on tuffite and for $\mathrm{LV}_{13}$ $\left(4,496 \mathrm{mg} \mathrm{kg}^{-1}\right)$ from gabbro (Figure 7). For soils formed on tuffite $\operatorname{LV}_{8}\left(2,533 \mathrm{mg} \mathrm{kg}^{-1}\right)$ and $\mathrm{LV}_{10}\left(2,906 \mathrm{mg} \mathrm{kg}^{-1}\right)$, these values were similar to those found in basalt soils (mean of 2,285 mg kg-1) $\left(\mathrm{LV}_{1}, \mathrm{LV}_{2}, \mathrm{LV}_{3}\right.$ and $\left.\mathrm{LV}_{4}\right)$ and the smallest contents were observed for $\mathrm{LV}_{5}\left(963 \mathrm{mg} \mathrm{kg}^{-1}\right.$ ) and $L_{6}\left(1,125 \mathrm{mg} \mathrm{kg}^{-1}\right)$. These findings suggest that diverse chemical compositions of tuffite-originated soils are attributed to the very heterogeneous nature of this rock (Ferreira et al., 1994).

In $\mathrm{LV}_{13}$, soil originating from gabbro, the higher TE concentration of the parent material may be the reason of the high contents observed. For most elements

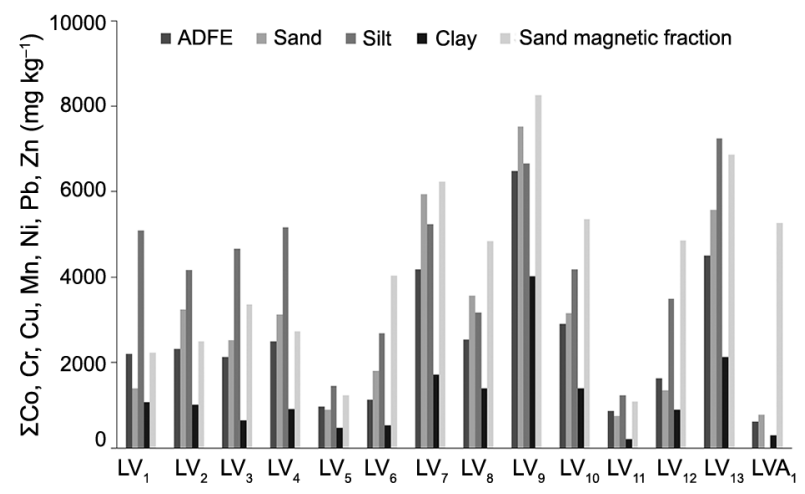

Figure 7 - Contents of $\mathrm{Co}, \mathrm{Cr}, \mathrm{Cu}, \mathrm{Mn}, \mathrm{Ni}, \mathrm{Pb}$ and $\mathrm{Zn}$ determined in ADFE (air-dried fine earth), sand, silt, clay fractions and in the sand magnetic fraction. analyzed, basalt soils $\left(\mathrm{LV}_{1}, \mathrm{LV}_{2}, \mathrm{LV}_{3}\right.$ and $\left.\mathrm{LV}_{4}\right)$ showed total concentrations within the observed mean for Brazilian Cerrado soils (Marques et al., 2004), which reflects the greater homogeneity of the parent rock material and stage of soil development.

When soil fractions were analyzed separately (Figure 7), higher values of the sum of the total TE contents in the coarse fractions (sand and silt) were found mainly in the magnetic sand fraction. Sand and silt fractions represent the source of soil chemical elements, especially TE for the medium and long term (Oliveira et al., 2000). According to Tiller (1980), prediction of plant availability of micronutrients based on total chemical analysis may be limited with possible negative correlations. Nevertheless, considering the equilibrium conditions of soil-solution after absorption by plants, soils with higher TE amounts could show greater speed of metal replenishment.

The clay fraction showed the lowest total TE contents values (Figure 7), indicating that these elements are partially lost during transformation/neoformation of minerals once TE are usually present as isomorphic substituent and/or fixed to colloidal surface of secondary minerals in contrast to the major elements. The correlation observed between TE contents of coarse fractions (magnetic sand $(r=0.77, p<0.01, n=14)$, sand $(r$ $=0.91, p<0.01, n=14)$ and silt $(r=0.74, p=0.01$, $n=14$ ) fractions) and those of the clay fraction suggests a pathway for superparamagnetic particles formation. Magnetite/maghemite superparamagnetic particles are probably originated from the oxidation/transformation process of magnetite/titanomagnetite multidomain magnetic particles from the parent rock material, which promoted a significant loss of TE contents in the clay fraction. It is not possible to know whether these close correlations between total TE contents of different fractions would happen if superparamagnetic particles, especially maghemite, were formed from pedogenic antiferrimagnetic $\mathrm{Fe}$ oxides, such as hematite and/or goethite.

The $\mathrm{Ti}_{\mathrm{s}}$ content showed a positive relationship with the sum of the total TE contents (Figure 8A). This suggests the importance of $\mathrm{Ti}$ and/or Fe-Ti oxides as a reserve of these elements or even the use of $\mathrm{Ti}$ as a richness indicator of the parent material in terms of some $\mathrm{TE}$ in soils originating from mafic rocks.

The correlation between $\mathrm{Fe}_{\mathrm{s}}$ and total TE contents is poor (Figure $8 \mathrm{~B}$ ), but the overall positive relationship supports the idea of geochemical affinity between Fe and these elements (Krauskopf, 1972). The LV $_{11}$ soil shows poor incorporation of the parent material (itabirite) in terms of TE contents (Oliveira et al., 2000). Itabirite is a rock formed by metamorphism of highly weathered Ferich sediment and quartz, which presents low contents of minor elements, such as $\mathrm{Cr}, \mathrm{Co}, \mathrm{Ni}, \mathrm{Cu}, \mathrm{Zn}$, and several others (Klein and Ladeira, 2000; 2002; Spier et al., 2005). Although this fact for itabirite does not indicate absence of geochemical affinity with $\mathrm{Fe}$, this finding reveals that the geochemical affinity between Fe and certain TE is bet- 

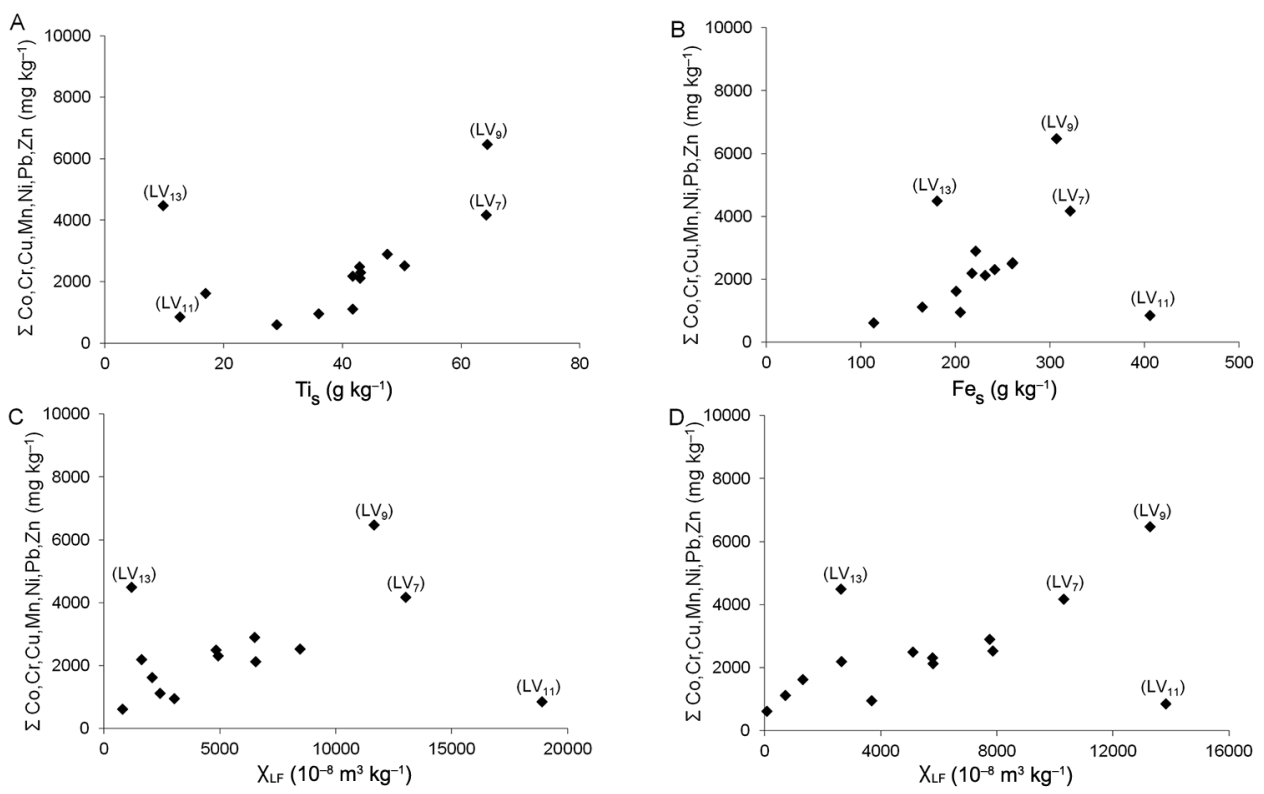

Figure 8 - Total contents of $\mathrm{Co}, \mathrm{Cr}, \mathrm{Cu}, \mathrm{Mn}, \mathrm{Ni}, \mathrm{Pb}$ and $\mathrm{Zn}$ determined in ADFE according to contents of $\mathrm{Ti}(\mathrm{A})$ and Fe (B) extracted by sulfuric digestion in ADFE (air-dried fine earth) and mass specific magnetic susceptibility $\left(\chi_{L F}\right)$ obtained in the sand (C) and clay (D) fractions.

ter expressed in soils originating from rocks formed in richer ionic environments, such as during magma cooling for formation of basic rocks. Studies have shown that soils derived from itabirite may have either low (Curi and Franzmeier, 1987) or high TE contents (Oliveira et al., 2000; Costa et al., 2014); therefore, generalizations regarding TE contents and parent material should be avoided.

Close correlations exist between values of magnetic susceptibility $\left(\chi_{\mathrm{LF}}\right)$ and TE concentrations (Figure $8 \mathrm{C}$ and D), as reported by Oliveira et al. (2000), due to the greater concentrations of these elements in ferrimagnetic minerals (magnetite, maghemite and intermediate phases). Along with the significant correlations observed between TE contents in coarse fractions and in the clay fraction, the results support the genesis pathway of superparamagnetic particles from multidomain magnetic particles cited above. However, we observed opposite trends of $\chi_{\mathrm{LF}}$ values for $\mathrm{LV}_{11}$ and $\mathrm{LV}_{13}$ soils, although the relationships observed between $\chi_{\mathrm{LF}}$ values and some TE contents of sand and clay fractions confirmed the geochemical associations between $\mathrm{TE}$ and ferrimagnetic minerals from basic rocks, but with less intensity for itabirite. Therefore, it appears that ferrimagnetic minerals in igneous rocks such as basalt, gabbro, and tuffite are richer in TE when compared to the same minerals in metamorphic rocks as itabirite and amphibolites. Oliveira et al. (2000) also reported better geochemical associations between TE contents and ferrimagnetic minerals in basalt and diabase compared to the same minerals in itabirite. Curi and Franzmeier (1987) studied soils derived from basalt and itabirite and highlighted that TE may be associated with magnetite grains.
Therefore, even in highly weathered soils such as Oxisols, the parent material still plays an important geochemical role to influence the behavior of these soils in terms of TE contents. Carvalho Filho et al. (2015) also showed the effect of the parent material in highly weathered soils and suggested re-evaluation of paradigms concerning the importance of the parent material only for poorly developed soils.

\section{Conclusions}

Fe-rich Oxisols in this study presented a typical mineralogical composition of highly weathered soils with structural stability. Results confirm the difficulty to identify accurately magnetic minerals in different grain sizes using X-ray diffraction methods. However, integrated analyses of magnetic and mineralogical studies showed that the coarse fractions still exert dominant influence on the magnetic properties of the Fe-rich Rhodic Oxisols developed from mafic rocks in Brazil and it possibly contributes to the enrichment of superparamagnetic particles for the clay size fraction. Although highly weathered, Ferich Oxisols may have their geochemical attributes still controlled by the parent material, where certain trace elements seem to be correlated with the magnetic minerals, especially those found in coarse fractions. Thus, the natural replacement of some trace elements in soil-solution equilibrium reactions during plant development could be more effective in soils with higher magnetic particles concentrations in the coarse fractions. We have suggested two questions for further studies:

1) Could lithogenic and pedogenic fractions of magne- 
tite/maghemite be isolated using coercivity unmixing to determine if one of these populations is better correlated with concentrations of trace elements?

2) Could element maps created with scanning or transmission electron microscopy better determine if the trace elements were sorbed to mineral surfaces or incorporated pervasively within mineral lattices?

\section{Acknowledgments}

The authors wish to thank Coordination for the Improvement of Higher Level Personnel (CAPES) for the financial support.

\section{References}

Camargo, L.A.; Marques, J.; Pereira, G.T.; Souza Bahia, A.S.R. 2014. Clay mineralogy and magnetic susceptibility of Oxisols in geomorphic surfaces. Scientia Agricola 71: 244-256.

Camêlo, D.L.; Ker, J.C.; Fontes, M.P.F.; Corrêa, M.M.; Costa, A.C.S.; Melo, V.F. 2017. Pedogenic iron oxides in iron-rich Oxisols developed from mafic rocks. Revista Brasileira de Ciência do Solo 41: e0160379.

Carvalho Filho, A.; Inda, A.V.; Fink, J.R.; Curi, N. 2015. Iron oxides in soils of different lithological origins in Ferriferous Quadrilateral (Minas Gerais, Brazil). Applied Clay Science 118: 1-7.

Cervi, E.C.; Costa, A.C.S.; Souza Junior, I.G. 2014. Magnetic susceptibility and the spatial variability of heavy metals in soils developed on basalt. Journal of Applied Geophysics 111: 377-383.

Costa, A.C.S.; Bigham, J.M.; Rhoton, F.E.; Traina, S.J. 1999. Quantification and characterization of maghemita in soils derived from volcanic rocks in southern Brazil. Clays and Clay Minerals 47: 466-473.

Costa, S.A.D.; Ker, J.C.; Simões, D.F.F.; Fontes, M.P.F.; Fabris, J.D.; Andrade, F.V. 2014. Pedogenesis and classification of latosols developed from itabirites in the region of Quadrilátero Ferrífero in Minas Gerais. Revista Brasileira de Ciência do Solo 38: 359-371 (in Portuguese, with abstract in English).

Curi, N.; Franzmeier, D.P. 1984. Toposequence of Oxisols from the central Plateau of Brazil. Soil Science Society of America Journal 48: 341-346.

Curi, N.; Franzmeier, D.P. 1987. Effect of parent rocks on chemical and mineralogical properties of some Oxisols in Brazil. Soil Science Society of America Journal 51: 153-158.

Dearing, J. 1999. Environmental Magnetic Susceptibility: Using the Bartington MS2 System. 2ed. Chi Publishing, Oakham, UK.

Empresa Brasileira de Pesquisa Agropecuária [Embrapa]. 2011. Manual of Soil Analysis Methods = Manual de Métodos de Análise de Solos. 2ed. Embrapa Solos, Rio de Janeiro, RJ, Brazil (in Portuguese).

Empresa Brasileira de Pesquisa Agropecuária [Embrapa]. 2013. Brazilian System of Soil Classification $=$ Sistema Brasileiro de Classificação de Solos. 3ed. Embrapa, Brasília, DF, Brazil (in Portuguese).

Fabris, J.D.; Jesus Filho, M.F.; Mussel, W.N.; Coey, J.M.D.; Goulart, A.T. 1997a. Iron-rich spinels from Brazilian soils. Hyperfine Interactions 110: 23-32.
Fabris, J.D.; Mussel, W.N.; Coey, J.M.D.; Jesus Filho, M.F.; Goulart, A.T. 1997b. Mg-rich iron oxide spinels from tuffite. Hyperfine Interactions 110: 33-40.

Ferreira, S.A.D.; Santana, D.P.; Fabris, J.D.; Curi, N.; Nunes Filho, E.; Coey, J.M.D. 1994. Magnetization, trace elements and lithology in two soil sequences from Minas Gerais state, Brazil. Revista Brasileira de Ciência do Solo 18: 167-174 (in Portuguese, with abstract in English).

Fontes, M.P.F.; Oliveira, T.S.; Costa, L.M.; Campos, A.A.G. 2000. Magnetic separation and evaluation of magnetization of Brazilian soils from different parent materials. Geoderma 96: 81-99.

Fontes, M.P.F.; Weed, S.B. 1991. Iron oxides in selected Brazilian Oxisols. I. Mineralogy. Soil Science Society of America Journal 55: 1143-1149.

Hanesch, M.; Rantitsch, G.; Hemetsberger, S.; Scholger, R. 2007. Lithological and pedological influences on the magnetic susceptibility of soil: their consideration in magnetic pollution mapping. Science of the Total Environment 382: 351-363.

Inda, A.V.; Torrent, J.; Barrón, V.; Bayer, C.; Fink, J.R. 2013. Iron oxides dynamics in a subtropical Brazilian Paleudult under long-term no-tillage management. Scientia Agricola 70: 48-54.

Jackson, M.L. 1979. Soil Chemical Analysis: Advanced Course. 2ed. Dept. Soil Science, University of Wisconsin, Madison, WI, USA.

Klein, C.; Ladeira, E.A. 2000. Geochemistry and petrology of some proterozoic Banded Iron-Formations of the quadrilatero ferrífero, Minas Gerais, Brazil. Economic Geology 95: 405-428.

Klein, C.; Ladeira, E.A. 2002. Petrography and geochemistry of the least altered Banded Iron-Formation of the Archean Carajás formation, northern Brazil. Economic Geology 97: 643-651.

Krauskopf, K.B. 1972. Geochemistry of micronutrients. p. 7-40. In: Mortvedt, J.J.; Giordano, P.M.; Lindsay, W.M., eds. Micronutrients in agriculture. Soil Science Society of America, Madison, WI, USA.

Lu, S.G. 2000. Lithological factors affecting magnetic susceptibility of subtropical soils, Zhejiang Province, China. Catena 40: 359-373.

Lu, S.G. 2003. Chinese Soil Magnetism and Environments. Higher Education Press, Beijing, China.

Lu, S.G.; Xue, Q.F.; Zhu, L.; Yu, J.Y. 2008. Mineral magnetic properties of weathering sequence of soils derived from basalt in eastern China. Catena 73: 23-33.

Maher, B.A. 1986. Characterization of soils by mineral magnetic measurements. Physics of the Earth and Planetary Interiors 42: 76-92.

Marques, J.J.; Schulze, D.G.; Curi, N.; Mertzman, S.A. 2004. Trace element geochemistry in Brazilian Cerrado soils. Geoderma 121: 31-43.

Mehra, J.P.; Jackson, M.L. 1960. Iron oxides removal from soils and clays by a dithionite-citrate-bicarbonate system buffered with bicarbonate sodium. Clays and Clay Minerals 7: 317-327.

Norrish, K.; Taylor, M. 1961. The isomorphous replacement of iron by aluminium in soil goethites. Soil Science 12: 294-306.

Oliveira, T.S.; Fontes, M.P.F.; Costa, L.M.; Horn, A.H. 2000. Relationship between magnetization and trace elements content of Brazilian soils from different parent materials. Soil Science 165: 825-834. 
Silva, A.R.; Souza Junior, I.G.; Costa, A.C.S. 2010. Magnetic susceptibility of B horizon of soils in the state of Paraná. Revista Brasileira de Ciência do Solo 34: 329-337 (in Portuguese, with abstract in English).

Soil Survey Staff. 2014. Keys to Soil Taxonomy. 12ed. USDANatural Resources Conservation Service, Washington, DC, USA.

Soltanpour, P.V.; Johnson, G.W.; Workman, S.M.; Jones Jr., J.B.; Miller, R. 1996. Inductively coupled plasma emission spectrometry and inductively coupled plasma-mass spectroscopy. p. 91-140. In: Sparks, D.L., ed. Methods of soil analysis. Part 3. Chemical methods. Soil Science Society of America, Madison, WI, USA.
Spier, C.A.; Oliveira, S.M.B.; Rosière, C.A.; Ardisson, J.D. 2005. Mineralogy and trace-element geochemistry of the high-grade iron ores of the Águas Claras Mine and comparison with the Capão Xavier and Tamanduá iron ore deposits, Quadrilátero Ferrífero, Brazil. Mineralium Deposita 43: 229-254.

Tiller, K.G. 1980. Micronutrients. p. 365-388. In: CSIRO Division of Soils. Soils: an Australian viewpoint. CSIRO, Clayton, Australia.

Torrent, J.; Barrón, V.; Liu, Q. 2006. Magnetic enhancement is linked to and precedes hematite formation in a aerobic soil. Geophysical Research Letters 33: L02401. 